UDC 811.111 42

DOI 10.32999/ksu2663-2691/2019-77-11
PhD in Pedagogy,

S. Ostapenko

Associate Professor,

the head of the department

of Foreign Philology and Translation,

Donetsk National University of

Economics and Trade named after

Mykhailo Tugan-Baranovsky

\section{H. Udovichenko}

PhD in Pedagogy,

the assistant professor of the

department of Foreign Philology

and Translation,

Donetsk National University of

Economics and Trade named after

Mykhailo Tugan-Baranovsky

\title{
LINGUOCULTURAL APPROACH TO LANGUAGE LEARNING AND COGNITIVE LINGUISTICS AS BASIC NOTIONS OF MODERN LANGUAGE STUDIES
}

Modern linguistics regards language as a social phenomenon closely connected with the culture and history of a particular people. The focus is on the identity of the native speaker, which is revealed through the study of the human language, reflects the spiritual essence, motivation and value hierarchy existing in the mind of the native speaker. The language in a person and a person in a language is analyzed, the phrases and expressions that he most often uses, to which he has the highest level of empathy. The human intellect, like a man himself, is unthinkable outside of language and language ability as the ability to create and perceive speech. Language interferes with all thought processes, creates new mental spaces.

Analysis of recent researches and publications. Representatives of the cognitive approach in semantics are mainly American scientists Ch. Au. Beard, A. Cienki, Ch. J. Fillmore, G. Fauconnier, A.E. Goldberg, R. Jackendoff, G. Lakoff, R.W. Langacker, B. Rudzka-Ostyn, L. Talmy, G. Taylor. In the domestic linguistics, the problems of cognitive linguistics are dealt with Yu. Apresian, M. Boldyrev, I. Brovchenko, O. Vorobiova, S. Zhabotynska, V. Karasyk, M. Kocherhan, T. Lunova, V. Manakin, M. Poliuzhyn, T. Radziievska, Y. Sternin, H. Ufimtseva, M. Tsehelska.

Problem statement. The purpose of this study is to analyze the latest publications and generalize the theoretical data of the conceptual apparatus of cognitive linguistics in modern linguistics.

Statement of the basic material. Cognitive linguistics examines the mental processes that occur during perception, comprehension, knowledge of reality by consciousness, as well as the types and forms of their mental representations. It is included as an integral part of cognitology - the integral science of cognitive processes in the mind of a person, providing operational thinking and knowledge of the world. Cognitology studies the models of consciousness associated with the processes of cognition, with the acquisition, production, storage, use, transfer of knowledge, the representation of knowledge and the processing of information coming to a person through various channels, processing knowledge, making decisions, understanding human speech, logical inference, argumentation and with other types of cognitive activity [9, c. 24].

The difference between cognitive linguistics and other cognitive sciences is in the material under study. It explores the mind on the material of the language. Cognitive linguistics is a linguistic direction in which the functioning of language is viewed as a kind of cognitive, that is, cognitive activity, and the cognitive mechanisms and structures of human consciousness are examined through linguistic phenomena [14, c. 169]. The methods of cognitive linguistics also differ from others. It explores cognitive processes, draws conclusions about the types of mental representations in the mind of a person based on the application of the linguistic methods of analysis available at their disposal, followed by a cognitive interpretation of the result of the study.

The key concept of cognitive linguistics is the concept of information and its processing by the human mind, the concept of knowledge structures and their representation in the consciousness of the individual and language forms. Together with other sciences that are part of cognitology, it tries to answer the question of how man's consciousness is organized, how a person percepts the world, how the information about the world becomes knowledge, how mental spaces are created. The meaning of language is extraordinary, it is through language, on the one hand, mental activity is objectified, and on the other, its study is a way of exploring cognition, since there are certain interrelationships between cognitive and linguistic structures. Cognitive linguistics explores how the structures of human knowledge are related to linguistic forms, as they are represented in the mind of man.

The subject of cognitive linguistics is the problem of the role of language in the processes of perception of the world, the processes of its design in the form of concepts fixed by linguistic signs, the problem of the correlation of concepts with linguistic world pictures.

With the help of language tools, the concepts of time, space, various objects and phenomena are formed; the ways of organizing the universe are modeled. Language reflects both the material aspects of the life of the people - the geographi- 
cal location, climate, life, and the spiritual sides of the speakers of the language - morality, the system of values, mentality, national character.

Language is one of the most divinely-human works, the universal heritage of mankind and the universal reality of social existence. This, according to the German philosopher Martin Heidegger, is the home of the human Spirit [3, c. 11]. Language is a dynamic system created and reproduced by speech organs, articulate sound marks for objects and phenomena of physical and mental activity and their reflections in consciousness, as well as rules for the compatibility of these signs - a system capable to express the fullness of human knowledge and ideas about the world. Language is the most complicated phenomenon. E. Benveniste wrote several decades ago, "The properties of the language are so peculiar that one can in fact speak of the presence in the speech of not one but several structures, each of which could serve as the basis for the emergence of integral linguistics" [2, c. 8]. This is a multidimensional phenomenon that has arisen in human society: it is the system and the antisystem, and the activity and product of this activity, and the spirit and matter, and the object that spontaneously develops, and the orderly self-regulating phenomenon, it is both arbitrary and created, etc. Characterizing language in all its complexity from opposite sides, we reveal its very essence.

Traditionally, there are three scientific paradigms, the study of language - a comparative-historical, system - structural and, finally, anthropocentric.

The comparative-historical paradigm was the first scientific paradigm in linguistics, since the comparative-historical method was the first special method of studying the language. All XIX century passed under the aegis of this paradigm.

With the system-structural paradigm, attention was focused on the subject, thing, name, so the focus was on the word. Even in the third millennium, one can study the language still within the system-structural paradigm because this paradigm continues to exist in linguistics, and the number of its followers is large enough. In the mainstream of this paradigm, textbooks and academic grammars are still being created, various types of reference books are being written. Fundamental research carried out within the framework of this paradigm is a valuable source of information not only for modern researchers, but also for future generations of linguists who already work in other paradigms.

And finally, the anthropocentric paradigm is the switching of the researcher's interests from the objects of cognition to the subject, that is, the person in the language and the language in the person are analyzed, because, according to Ivan Boduen de Kurtene, "language exists only in individual brains, only in the souls, only in the psyche of individuals or individuals that make up this linguistic society" [4, c. 10]. The idea of the language's anthropocentricity is the key one in modern linguistics. Nowadays the purpose of linguistic analysis can no longer be considered as simply a identification of various characteristics of the linguistic system. Awareness of oneself by the measure of all things gives the person the right to create in his consciousness an anthropocentric order of things, which can be investigated not on the everyday, but on the scientific level. This order, which exists in the head, in the mind of a person, determines its spiritual essence, the motives of its actions, and the hierarchy of values. All this can be understood by examining a person's language, those phases and expressions that he most often uses, to which he has the highest level of empathy.

In the process of forming a new scientific paradigm, the thesis was proclaimed: "The world is a collection of facts, not things" (Ludwig Josef Johann Wittgenstein) [12, c. 10]. The language was gradually reoriented to the fact, the event, and the personality of the language speaker (the linguistic personality, according to N. Karaulov) became the focus of attention [6, c. 37]. The human intellect, like man himself, is unthinkable outside of language and language ability, as the ability to create speech. If speech did not interfere with all thought processes, if it were not capable of creating new mental spaces, then man would not go beyond the immediate observable. At the same time, the difference between cognitive linguistics and other cognitive sciences lies precisely in its material - it explores the consciousness on the material of the language (other cognitive sciences explore the mind on its own material), as well as in its methods - it explores cognitive processes, draws conclusions about the types of mental representations in human consciousness on the basis of the application of available in linguistics of its own linguistic methods of analysis, followed by a cognitive interpretation of the results of the study.

Key concepts of cognitive linguistics are the concept of information and its processing by the human mind, the concept of knowledge structures and their representation in the mind of man and linguistic forms. If cognitive linguistics, together with cognitive psychology and cognitive sociology, try to answer the question of how the consciousness of man is generally organized, how a person sees the world, information about what becomes knowledge, how mental spaces are created, then all attention in linguoculturology is given to a person in culture and its language.

Linguoculturology studies language as a phenomenon of culture. This is a certain vision of the world through the prism of the national language, when the language acts as the spokesperson for a special national mentality.

Language serves as a means of accumulating and storing culturally relevant information. In some units, this information implicit for the modern native speaker, hidden by age transformations, can only be deleted indirectly. But it exists and "works" at the subconscious level.

All linguistics is permeated with cultural and historical content, since speech is its subject, it is the condition, the basis and the product of culture. At the end of the 20th century, in the words of Revekka Frumkina, "a sort of dead end has opened up: it turned out that in the science of man there is no place for the main thing that created man and his intellect culture" $[13$, c. 53$]$.

Since in most cases a person deals not with the world itself, but with its representations, with cognitive pictures and models, then the world appears through the prism of the culture and language of the people, sees this world. One cannot fail to see that there are many things in the life and behavior of a nation that are explained by cultural factors. For example, the obligatory presence of a patronymic in the Ukrainian person is a special honor and respect, which is given to him by fellow tribesmen. The Ukrainians say: by name they call, they patronize by the middle name. 
With all the difference in existing directions, the subject of modern linguoculturology is the study of the cultural semantics of linguistic signs, which is formed by the interaction of two different codes - language and culture, since each linguistic personality is also a cultural personality. Therefore, linguistic signs are able to perform the function of the "language" of culture, expressed in the ability of the language to reflect the cultural-national mentality of its bearers. In this regard, we can talk about a "cultural barrier", which can arise even if all language norms are observed.

Linguoculturology as an independent branch of knowledge must solve its specific tasks and at the same time answer first of all a number of questions: how culture participates in the formation of linguistic concepts; to which part of the meaning of the linguistic sign "cultural meanings" are attached; if these meanings are intelligible to the speaker and the listener and how they affect speech strategies; whether the cultural and linguistic competence of the native speaker exists in reality, on the basis of which cultural meanings are embodied in texts and recognized by native speakers; what conceptual spheres (set of the main concepts of this culture) are oriented to the representation by the bearers of one culture, the set of cultures (universals); how to systematize the basic concepts of this science, that is, to create a conceptual apparatus that would not only allow analyzing the problem of the language's interaction and culture in dynamics, but would provide mutual understanding within the framework of this scientific paradigm - anthropological or anthropocentric - as well. The above list of tasks cannot be considered final, as progress in their solution will create the next cycle of tasks, etc.

As a working definition of cultural-linguistic competence, we adopt the following: it is the natural command of processes of language creation and language perception by the linguistic personality and, most importantly, the command of cultural attitudes.

Let's dwell on some of the concepts of linguoculture, which are especially significant from the point of the linguisticpedagogical aspect.

1. The code of culture - according to the figurative definition of V. Krasnykh, it is some kind of invisible "network" that "culture throws on the world around, divides, categorizes, structures and evaluates it." In the language, culture codes are usually expressed using basic metaphors, on this basis anthropomorphic, zoomorphic, gastronomic and other cultural codes are distinguished.

2. Cultural concept - "... a clot of culture in the mind of man, then in the form of what culture enters his mental world. On the other hand, the concept is that by which a person enters culture himself, and in some cases influences it. "The most stable and permanent concepts that have a special axiological significance for the national culture are called key concepts or constants of culture.

3. Cultural attitudes - a kind of socio-cultural ideals, "mental patterns," which play the role of certain instructions for behavior, including the communicative one, of members of ethnosocium.

4. Cultural connotation - interpretation of the denotative or figuratively-motivated aspects of meaning in terms and categories of culture.

5. Cultural space - corresponds with the individual and collective cognitive space of the form of existence of culture in the minds of its representatives.

6. The language picture of the world - historically formed in the ordinary consciousness of a given language collective and reflects in the language a set of ideas about the world, a certain way of its conceptualization.

In modern cognitive linguistics, the concept is becoming pivotal, which as a term is increasingly used by researchers dealing with the problems of speech representation of cognitions [7, c. 26]. It is this key concept that distinguishes cognitive linguistics from other areas of semantics research. This concept does not have an unambiguous definition, the content of the concept varies very much in the concepts of various scientific schools and individual scientists. This is due to the fact that the concept has a dual essence - mental and verbal - and this gives a lot of room for interpretation.

V. Karasyk cites a number of approaches to the concepts proposed by different scientists: concept is an idea that includes abstract, concrete-associative and emotional-evaluative characteristics, as well as a compressed history of the concept; concept is personal comprehension, interpretation of objective meaning and concept as a meaningful minimum of meaning; concept is an abstract scientific notion, developed on the basis of a specific life concept; concept is the essence of the notion, phenomena in its content forms - in the image, concept, symbol; concept is unique cultural genes that enter the genotype of culture, integrated functional-system, multidimensional (at least three-dimensional) idealized formations, based on a conceptual or pseudo-conceptual basis [8, c. 12-13].

Australian researcher Anna Wierzbicka distinguishes: the concept-minimum is an incomplete knowledge of the meaning of a word (a certain reality, but not all that concerns it, in practice it is not important to it); the concept-maximum covers a comprehensive knowledge of the meaning of the word, its encyclopedic addition, professional knowledge of reality.

In the work of N. Arutiunov, the term concept is endowed with its own status. The use of this term is associated with the expansion of the subject field of linguistics through interaction with philosophy and psychology. With increasing interest to the problem of "man in language", the interpretation of the term concept began to focus on "the meaning that exists in man and for man, inter- and intrapsychic processes and communications" [10, c. 147-148].

According to Elena Kubrjakova the concept is a unit of consciousness and information structure, reflects human experience; as well as "an operational unit of memory of the whole picture of the world, a quantum of knowledge."

V.N. Teliia defines the concept as "all that we know about the object in the entire extensionality of this knowledge". It is the semantic category of the highest degree of abstraction, it includes the particular values of the concretization of general semantics.

In the studies of A. Zalevskaja concept is defined as the spontaneously functioning in the cognitive and communicative activity of the individual basic perceptually-cognitive-affective formation of a dynamic character, subject to the laws 
of a person's mental life, and consequently, for a number of specific parameters, differs from the concepts of values as products of scientific description from the standpoint of linguistic theory [5, c. 39].

One of the founders of the doctrine of the concept S. Askoldov defines it as "a thought formation that replaces in the process of thinking an indefinite multiplicity of objects of the same kind" [1, c. 269]. The concept is not always a substitute for real objects; it can replace certain parts of an object or real actions [1, c. 270].

Concepts are ideal and coded in consciousness by units of universal subject code that have a subject-shaped, that is, sensual character, and its universality is due to the fact that it is available to all without any except the native speakers, although it is different for each individual, because it reflects the subjective sensory experience of a person, personally received in real life through the senses. The unit of universal subject code is the most vivid, intuitive, stable personal part of the concept, it has a figurative nature. The image, making up the unit of the universal object code, can be accidental, unessential for the given concept precisely because of its purely personal, individual nature, but, nevertheless, it performs coding, sign functions for the concept as a whole.

Proceeding from this, the concept is born as a unit of universal subject code, which remains its core. The core is gradually enveloped, enveloped by layers of conceptual features, increases the volume of the concept and saturates its content.

The concept in the mind of a person arises as a result of activity, an experienced knowledge of the world, socialization and has its components: sensory experience; mental operations with the concepts already existing in his mind; objective human activity; speech knowledge; conscious cognition of speech units.

Thus, the conceptual education, which is the basic unit of the thinking code of a person possessing a relatively ordered internal structure and represents the result of the cognitive activity of the individual and society, carries complex, encyclopedic information about the displayed subject or phenomenon, the interpretation of this information by the public consciousness and the attitude of the public consciousness to this phenomenon or object.

Recently, one of the most important problems of cognitive linguistics has become the problem of reflecting in the human mind an integral picture of the world fixed in language. Man, gaining experience, transforms it into certain concepts, logically linking with each other, forms a conceptual system; it is constructed, modified and refined by a person continuously. Concepts, being a part of the system, fall under the influence of other concepts and are modified. Over time, the number of concepts varies, and the amount of their content varies as well [11, c. 30]. The picture of the world, which can be called knowledge of the world, lies at the heart of individual and public consciousness. Speech, in its turn, meets the requirements of the cognitive process. Conceptual pictures of the world of different people can be different, for example, representatives of different epochs, different social and age groups, different areas of scientific knowledge. People who speak different languages, under certain circumstances, can have close conceptual pictures of the world, and those who speak the same language - different ones. So, in the conceptual picture of the world, the universal, national, professional and personal notions co-operate. Since the emergence of a picture of the world is closely related to language and is largely determined by language, it is called the language picture of the world. In the process of person's life, the language picture of the world precedes the conceptual one and shapes it, because man is able to understand the world and himself thanks to language. It is in the language that social and historical experience is consolidated, both universal and national one. Under the conceptual picture of the world, linguists assume the body of knowledge about the world that is acquired in the process of human activity; ways and mechanisms of interpreting new knowledge. The language picture of the world is the common cultural heritage of the nation, it is structured, multilevel, it is the result of communicative behavior, understanding of the external and internal world of man $[12$, c. 120].

The conceptosphere is a purely mental sphere, consisting of concepts existing in the form of mental pictures, schemes, concepts, abstract entities that generalize the various signs of the external world [12, c. 140]. The language picture of the world is that part of the conceptosphere that has been expressed by means of linguistic signs, the totality of meanings transmitted by the linguistic signs of this language [11, c. 135]. Comparison of various language pictures of the world allows you to see panhuman universals in reflection, surrounding people, the world and at the same time provides an opportunity to see the specific, national, and then group, and individual in the set of concepts and their structuring.

The structure of the concept includes: image component; information content; interpretation field. The image component in the structure of the concept is binate: the percept-image - visual, tactile, taste, sound and smelling images; cognitive (metaphorical) image -cognitive, sensual-visual image that gives the abstract concept concrete figurative content, allows it to be fixed in the universal objective code of thinking. The information content of the concept includes a minimum of cognitive characteristics that determine the main, most important distinctive features of the conceptualized object or phenomenon. The content of many concepts is close to the content of the dictionary definition of the keyword concept. The interpretation field of the concept includes cognitive features that in one way or another interpret the basic informational content of the concept, influence it, representing some final knowledge, or evaluating it.

The following zones of the interpretation field are: 1) evaluation zone - combines cognitive features, expressing a general assessment, aesthetic, emotional, intellectual, etc.; 2) the encyclopedic zone-combines the cognitive features that characterize the characteristics of the concept, require familiarity with it on the basis of experience, training; 3) utilitarian zone - combines cognitive features expressing the utilitarian, pragmatic attitude of people to the concept detonator, knowledge associated with the possibility and peculiarities of its use for practical purposes; 4 ) the regulatory zone - combines cognitive features that attribute what is needed, and what not to do in the area, which is covered by the concept; 5) socio-cultural zone - combines cognitive features that reflect the connection of the concept with the life and culture of the people: traditions, customs, concrete figures of literature and art; 6) paremiological zone - a set of cognitive features of the concept, objectified by proverbs, sayings and aphorisms. 
In addition to the structure of the concept, the issue of classification or typology is important. The search for a definition of the concept and its mental specifics were closely related to the problem of classification of concepts, which the researchers paid much attention to. Nowadays, there is a large number of works devoted to this issue, in which various approaches to its solution are disclosed. In our opinion, it is most important to distinguish between concepts according to the type of knowledge, the reflection of reality, which they fix, because it is from this that the methods of identifying and describing concepts depend. The conducted research in this area allows us to propose the following typology of concepts: concept - representation - is objectified in the language primarily by lexical units of concrete semantics. The fact that the semantic aspect of such units is demonstrated by the presentation itself is evidenced by the vocabulary definitions of these lexemes, many of which practically consist of a list of sensually perceived features of the nomination subject; scheme-concept, represented by some generalized spatial-graphical or contour scheme; notion-concept reflecting the most common, significant features of an object or phenomenon, the result of their rational reflection and comprehension; frame - a multicomponent concept conceivable in the integrity of its components, a set of standard knowledge about the subject or phenomenon; scenario - the sequence of several episodes in time; these are stereotyped episodes with signs of movement, development; gestalt - a complex, holistic functional mental structure that regulates the diversity of individual phenomena in consciousness.

Also significant for linguocognitive studies is the classification of concepts by their belonging to certain groups of carriers. From this point of view, universal concepts and national concepts stand out. There are also group, age, gender, professional, and individual concepts.

Conclusions. Cognitive linguistics inherited the achievements of all linguistic paradigms that existed before it, and develops together with philosophy and psychology the existing problems of the links between language and thinking, but considers them in such categories as knowledge, linguistic varieties of knowledge, linguistic ways of representation of knowledge, procedures for operating knowledge, mental structures. Cognitive linguistics notes that part of the person's cognitive ability is his/her language ability. Thus, we come to the conclusion that for cognitive linguistics the following directions are inherent: the emergence into other sciences, the study of the language for the purpose of understanding its speakers, the study of the variety of functions of the language, the explanation of linguistic phenomena.

\section{References:}

1. Аскольдов С. Концепт и слово. Русская словесность. От теории словесности к структуре текста: антология / под общ. ред. В. Нерознака. Москва : Просвещение, 1997. С. 267-279.

2. Бенвевист Э. Общая лингвистика : монография. Москва : Прогресс, 1974. 448 с.

3. Білецький А. Про мову і мовознавство. Київ : Вища школа, 1996. 38 с.

4. Бодуэн де Куртэне И. Избранные труды. Москва : Академия, 1963. 384 с.

5. Залевская А. Психологический подход к проблеме концепта. Методологические проблемы когнитивной лингвистики. Воронеж : ВГУ, 2001. С. 12-16.

6. Караулов Ю. Русский язык и языковая личность. Москва : Наука, 1998. 271 с.

7. Карасик В., Слышкин Г. Базовые характеристики концептов. Антология концептов. Волгоград : Парадигма, 2005. $243 \mathrm{c}$.

8. Карасик В. Языковые концепты как измерения культуры. Архангельск : Гнозис, 1997. 475 с.

9. Кочерган М. Мовознавство на сучасному етапі. Дивослово. 2003. № 5. С. 24-29.

10. Куликова И., Салмина Д. Введение в металингвистику. Лингвистическая терминология в коммуникативно-прагматическом аспекте. Санкт-Петербург : САГА, 2002. 352 с.

11. Попова 3. Когнитивная лингвистика. Москва : Восток-Запад, 2007. 314 с.

12. Маслова В. Лингвокультурология : учебное пособие. Москва : Академия, 2001. 208 с.

13. Фрумкина Р. «Теории среднего уровня» в современной лингвистике. Вопросы языкознания. 1996. № 2. С. $55-67$.

14. Штерн I. Вибрані топіки та лексикон сучасної лінгвістики : енциклопедичний словник для фахівців 3 теоретичних гуманітарних дисциплін та гуманітарної інформатики. Київ : АртЕк, 1998. 336 с.

\section{S. OSTAPENKO, H. UDOVICHENKO. LINGUOCULTURAL APPROACH TO LANGUAGE LEARNING AND COGNITIVE LINGUISTICS AS BASIC NOTIONS OF MODERN LANGUAGE STUDIES}

Modern linguistics regards language as a social phenomenon closely connected with the culture and history of a particular people. The focus is on the identity of the native speaker, which is revealed through the study of the human language, reflects the spiritual essence, motivation and value hierarchy existing in the mind of the native speaker. Cognitive linguistics examines the mental processes that occur during perception, comprehension, knowledge of reality by consciousness, as well as the types and forms of their mental representations. It is included as an integral part of cognitology - the integral science of cognitive processes in the mind of a person, providing operational thinking and knowledge of the world. The article summarizes theoretical data concerning the conceptual apparatus of cognitive linguistics in modern language studies, defines the basic concept of cognitive linguistics - the concept, focuses on its multilayer character, evaluates the proposals on the methods for its classification and analysis.

Key words: scientific paradigm, comparative-historical paradigm, systemic-structural paradigm, anthropocentric paradigm, cognitive linguistics, linguoculture, cognitive linguistics, concept, concept sphere, methods of analysis and classification. 


\section{Анотація \\ С. ОСТАПЕНКО, Г. УДОВІЧЕНКО. ЛІНГВОКУЛЬТУРНИЙ ПІДХІД ДО ВИВЧЕННЯ МОВИ \\ ТА КОГНІТИВНА ЛІНГВІСТИКА ЯК ПРОВІДНІ ПАРАДИГМИ СУЧАСНОГО МОВОЗНАВСТВА}

Сучасна лінгвістика розглядає мову як соціальне явище, тісно пов'язане з культурою та історією конкретного народу. Основна увага приділяється особистості носія мови, яка виявляється через вивчення людської мови, відображає духовну сутність, мотивацію і ціннісну ієрархію, що існує в свідомості носія мови. Когнітивна лінгвістика вивчає розумові процеси, що виникають під час сприйняття, розуміння, пізнання дійсності свідомістю, а також типи і форми їх розумових уявлень. Вона є невід'ємною частиною когнітології - цілісна наука про когнітивні процеси в свідомості людини, що забезпечують операційне мислення і пізнання світу. У статті узагальнено теоретичні дані, що стосуються концептуального апарату когнітивної лінгвістики в сучасних мовних дослідженнях, визначено основну концепцію когнітивної лінгвістики - поняття, увагу зосереджено на його багатошаровому характері, оцінюються пропозиції щодо методів його класифікації та аналізу. Проаналізовано три наукові парадигми щодо вивчення мови - порівняльно-історична, системноструктурна та антропоцентрична. Визначено основні напрями сучасної лінгвістики, що формуються в межах цих парадигм - когнітивна лінгвістика та лінгвокультура. Висвітлено особливо значущі поняття 3 точки зору лінгводидактичного аспекту - кодекс культури, культурна концепція, культурні умови, культурна конотація, культурний простір, мовна картина світу. Обгрунтовано твердження, що лінгвокультура є гуманітарною дисципліною, яка вивчає матеріальну і духовну культуру, втілену в живій мові та відображену в лінгвістичних процесах. Це також дозволяє встановити і пояснити, як реалізується одна з основоположних функцій мови бути інструментом створення, розвитку, збереження та поширення культури.

Ключові слова: наукова парадигма, порівняльно-історична парадигма, системно-структурна парадигма, антропоцентрична парадигма, когнітивна лінгвістика, лінгвокультурологія, когнітивна лінгвістика, концепт, концептосфера, методи аналізу та класифікації. 